\begin{tabular}{|c|c|c|}
\hline \multirow{3}{*}{$\begin{array}{r}\text { Case Reports in } \\
\text { Gastroenterology }\end{array}$} & \multirow{2}{*}{\multicolumn{2}{|c|}{ Case Rep Gastroenterol 2016;10:399-405 }} \\
\hline & & \\
\hline & $\begin{array}{l}\text { DOI: 10.1159/000446578 } \\
\text { Publisnea onine: July z9, } 2016\end{array}$ & $\begin{array}{l}\text { (c) } 2016 \text { The Author(s) } \\
\text { Published by S. Karger AG, Basel } \\
\text { www.karger.com/crg }\end{array}$ \\
\hline & \multicolumn{2}{|c|}{$\begin{array}{l}\text { This article is licensed under the Creative Commons Attribution-NonCommercial } 4.0 \\
\text { International License (CC BY-NC) (http://www.karger.com/Services/OpenAccessLicense). } \\
\text { Usage and distribution for commercial purposes requires written permission. }\end{array}$} \\
\hline
\end{tabular}

\title{
Gastrointestinal Stromal Tumor of the Stomach with an Abscess Excised by Laparoscopic Surgery
}

\author{
Yoshiaki Maeda Toshiki Shinohara Tomonari Katayama \\ Akihisa Nagatsu Noriaki Futakawa Tomonori Hamada \\ Department of Gastrointestinal Surgery, Hokkaido Cancer Center, Sapporo, Japan
}

\section{Keywords}

Gastrointestinal stromal tumor - Abscess - Gastric gastrointestinal stromal tumor . Laparoscopic surgery

\begin{abstract}
Gastrointestinal stromal tumors (GISTs) of the stomach presenting as an intra-abdominal abscess are extremely rare. We herein report a case that underwent successful laparoscopic resection of gastric GIST presenting with an intra-abdominal abscess. A 70-year-old man presented with a 3-day history of acute upper abdominal pain with a fever. Laboratory data showed an elevated white blood cell count and C-reactive protein level. A CT scan revealed a mass of mixed solid and fluid components, measuring $5.5 \mathrm{~cm}$, in the adjacent lesser curvature of the stomach. He was diagnosed as having an intraabdominal abscess, and antibiotic therapy was administered. Consequently, his symptoms were relieved and a CT scan on the 7th day showed that the mass reduced and became homogenous. According to the results of a fine-needle aspiration biopsy, the tumor was suspected to be a GIST. Laparoscopic surgery with the 5-port approach was performed. The tumor existed in the lesser curvature of the stomach, and was excised en bloc with the omentum and gastric wall by wedge resection. The tumor measured $3.0 \mathrm{~cm}$ in diameter and originated from the serosal layer of the stomach. Histological findings showed spindle cells with a stromal growth pattern that was positive for c-kit (CD 117) and CD 34. The postoperative course was uneventful, and no recurrence has been noted in the 2 years since the operation. This is the first report of a case with gastric GIST with an intra-abdominal abscess that was successfully treated by laparoscopic surgery.

(C) 2016 The Author(s)

Published by S. Karger AG, Basel
\end{abstract}

KARGER
Yoshiaki Maeda

Department of Gastrointestinal Surgery

Hokkaido Cancer Center

3-54 Kikusui, Shiroishi-ku, Sapporo 003-0804 (Japan)

E-Mail maeda@sap-cc.go.jp 


\section{Case Reports in Gastroenterology}

Case Rep Gastroenterol 2016;10:399-405

(c) 2016 The Author(s). Published by S. Karger AG, Basel www.karger.com/crg

Maeda et al.: Gastrointestinal Stromal Tumor of the Stomach with an Abscess Excised by Laparoscopic Surgery

\section{Introduction}

Gastrointestinal stromal tumors (GISTs) are the most common sarcoma of the gastrointestinal tract. GISTs are malignancies that arise from intestinal cells of Cajal, which are pace maker cells in the bowel wall, and the stomach is the most common location of GISTs [1,2]. Surgical resection is the primary and only curative treatment of GISTs without dissemination or distant metastases. For relatively small gastric GISTs, laparoscopic resection has been reported to be a safe and effective treatment option associated with a significantly shorter hospital stay [3, 4]. However, in cases with bulky or complicated GISTs, the indications for laparoscopic surgery remain controversial since laparoscopic procedures may be difficult in such cases, or even compromise the oncologic outcomes [5-7].

GISTs involving the stomach presenting as an intra-abdominal abscess are extremely rare, and only 7 cases have been reported in the English literature [8-14]. To the best of our knowledge, all of these reported cases were treated by conventional open surgery. We herein report the first case treated by laparoscopic surgery for gastric GIST presenting with an intra-abdominal abscess.

\section{Case Presentation}

A 70-year-old man presented with a 3-day history of acute upper abdominal pain. He had a fever of $38.1^{\circ} \mathrm{C}$ and tenderness in the upper abdomen. The patient had not been taking medications and his past history was unremarkable. Laboratory data showed a white blood cell count of $14,000 / \mathrm{mm}^{3}$ and C-reactive protein level of $11.8 \mathrm{mg} / \mathrm{dl}$. A contrast-enhanced CT scan of the abdomen revealed a mass of mixed solid and fluid components, measuring 5.5 $\mathrm{cm}$, adjacent to the lesser curvature of the stomach (fig. 1a). He underwent gastrointestinal endoscopy, which revealed a submucosal tumor near the gastric angle without an ulcer or fistula. According to these findings, he was diagnosed as having an intra-abdominal abscess, and sulbactam/cefoperazone sodium $2 \mathrm{~g}$ /day was administered for 10 days. Consequently, the fever decreased, his symptoms relieved and the laboratory data improved. A contrastenhanced CT scan on the 7th day showed mass reduction (5.5-3.5 cm) (fig. 1b). An endoscopic ultrasound examination was performed on the 30th day, which showed a submucosal tumor with mixed hypoechoic changes (fig. 1c). A fine-needle aspiration biopsy was performed, and the tumor was diagnosed as GIST.

Laparoscopic surgery with the 5-port approach (fig. 2a) was performed to excise the tumor on the 70th day from the first presentation. Laparoscopic findings showed that the tumor existed in the lesser curvature of the stomach and adhered to the omentum. Wedge resection of the stomach was performed using a linear stapler, and the tumor was excised en bloc with the omentum and gastric wall (fig. $2 b-d$ ).

The excised tumor measured $3.0 \times 2.5 \mathrm{~cm}$ in diameter and originated from the serosal layer of the stomach, without an obvious fistula between the gastric lumen and the tumor. Histological findings showed spindle cells with a stromal growth pattern without necrosis (fig. 3a). The tumor was positive for c-kit (CD 117) and CD 34 (fig. 3b, c), with a Ki-67 index of $8 \%$ and mitosis of $<5 / 50 \mathrm{HPF}$, and was accordingly diagnosed as low-risk GIST. The postoperative course was uneventful, and the patient was discharged on postoperative day 12 . Imatinib mesylate was administered as adjuvant treatment, and no recurrence has been noted for 2 years after operation. 
Maeda et al.: Gastrointestinal Stromal Tumor of the Stomach with an Abscess Excised by Laparoscopic Surgery

\section{Discussion}

GISTs are understood to be specific KIT- or PDFGRA-driven mesenchymal gastrointestinal tract tumors, and a majority of these tumors (more than 60\%) occur in the stomach [1, 2]. The availability of a KIT and PDGFRA tyrosine kinase inhibitor, imatinib mesylate, has dramatically changed treatment strategies for metastatic or unresectable GISTs [15]; however, surgical resection remains the only curative treatment.

Cases of GISTs involving the stomach presenting as an intra-abdominal abscess are extremely rare, and only 7 cases have been reported in the English literature (table 1) [8-14]. In some cases with GISTs, tumor degeneration or necrosis can result in bleeding into the gastrointestinal lumen or peritoneum space, and bleeding into the intra-abdominal space can cause an intra-abdominal abscess. Five of 7 reported cases had a tumor with an ulcer or fistula in the lumen on macroscopic findings, and tumor necrosis was observed in 5 cases on histological examination. The presence of an ulcer, fistula, and necrosis may increase the risk of abscess formation; however, the present case and the case reported by Swain et al. [9] had no ulcer, fistula, or necrosis. The precise reason for abscess formation in these cases was unclear. We speculate that a minor hemorrhage occurred around the tumor, and subsequently bacterial infection via the gastrointestinal tract or blood stream might have resulted in abscess formation in these two cases.

For relatively small gastric GISTs, laparoscopic resection has been reported to be associated with favorable short-term outcomes without compromising the oncologic results [3,4]. However, the indications for laparoscopic surgery should be carefully discussed for cases with bulky (larger than $5 \mathrm{~cm}$ ) and high-risk tumors [5]. Therefore, most surgeons prefer conventional open surgery for large or complicated tumors to avoid tumor manipulation, which may cause dissemination or port site metastases $[6,7]$.

In the present case, the tumor and abscess coexisted at the time of initial hospitalization; however, the abscess was controlled by intravenous antibiotic therapy, and consequently the tumor was safely excised by laparoscopic surgery with sufficient surgical margins. To the best of our knowledge, this is the first report written in the English language of a case with gastric GIST with an intra-abdominal abscess treated by laparoscopic surgery.

\section{Conclusion}

We herein reported the case of stomach GIST with an intra-abdominal abscess that was successfully excised by laparoscopic surgery.

\section{Statement of Ethics}

The authors have no ethical conflicts to disclosure. Informed consent was obtained from the presented patient.

\section{Disclosure Statement}

The authors have no conflicts of interest to declare. 


\section{Case Reports in \\ Gastroenterology}

Case Rep Gastroenterol 2016;10:399-405

(c) 2016 The Author(s). Published by S. Karger AG, Basel www.karger.com/crg

Maeda et al: Gastrointestinal Stromal Tumor of the Stomach with an Abscess Excised by Laparoscopic Surgery

\section{References}

1 Miettinen M, Sobin LH, Lasota J: Gastrointestinal stromal tumors of the stomach: a clinicopathologic immunohistochemical, and molecular genetic study of 1,765 cases with long-term follow-up. Am J Surg Pathol 2005;29:52-68

- Hirota S, Isozaki K, Moriyama Y, Hashimoto K, Nishida T, Ishiguro S, Kawano K, Hanada M, Kurata A, Takeda M, Muhammad Tunio G, Matsuzawa Y, Kanakura Y, Shinomura Y, Kitamura Y: Gain-of-function mutations of c-kit in human gastrointestinal stromal tumors. Science 1998;279:577-580.

-3 Pelletier JS, Gill RS, Gazala S, Karmali S: A systematic review and meta-analysis of open vs laparoscopic resection of gastric gastrointestinal stromal tumors. J Clin Med Res 2015;7:289-296.

-4 Piessen G, Lefèvre JH, Cabau M, Duhamel A, Behal H, Perniceni T, Mabrut JY, Regimbeau JM, Bonvalot S, Tiberio GA, Mathonnet M, Regenet N, Guillaud A, Glehen O, Mariani P, Denost Q, Maggiori L, Benhaim L, Manceau G, Mutter D, Bail JP, Meunier B, Porcheron J, Mariette C, Brigand C; AFC and the FREGAT working group: Laparoscopic versus open surgery for gastric gastrointestinal stromal tumors: what is the impact on postoperative outcome and oncologic results? Ann Surg 2015;262:831-839; discussion 829-840.

-5 Nishimura J, Nakajima K, Omori T, Takahashi T, Nishitani A, Ito T, Nishida T: Surgical strategy for gastric gastrointestinal stromal tumors: laparoscopic vs open resection. Surg Endosc 2007;21:875-878.

-6 Davies AR, Ahmed W, Purkiss SF: Port site metastasis following diagnostic laparoscopy for a malignant gastro-intestinal stromal tumour. World J Surg Oncol 2008;6:55.

-7 Hachim H, Majbar AM, Alaoui M, Raiss M, Sabbah F, Hrora A, Ahallat M: Abdominal wall recurrence of a gastrointestinal stromal tumor: case report. Springerplus 2015;4:429.

-8 Yardimci S, Uprak TK, Kombak FE, Kaya H, Yegen SC: Ruptured gastric stromal tumour into gastric lumen with an abscess. ANZ J Surg 2014;84:687-689.

-9 Swain SK, Smile R, Arul T, David D: Unusual presentation of gastrointestinal stromal tumor of stomach in neurofibromatosis type 1: a case report. Indian J Surg 2013;75(suppl 1):398-400.

10 Altaca G, Demiralay E, Kalayci SA, Hobek AA, Karakayali H, Haberal M: Giant malignant gastrointestinal stromal tumor presenting as an intraabdominal abscess. J Gastrointestin Liver Dis 2009;18:515-516.

11 Osada T, Nagahara A, Kodani T, Namihisa A, Kawabe M, Yoshizawa T, Ohkusa T, Watanabe S: Gastrointestinal stromal tumor of the stomach with a giant abscess penetrating the gastric lumen. World J Gastroenterol 2007;13:2385-2387.

12 Nozawa S, Bando T, Nagata T, Tsukada K: Abscess formation in a giant gastrointestinal stromal tumor of the stomach following endoscopic biopsy. Endoscopy 2006;38:955.

13 Seidel RH Jr, Burdick JS: Gastric leiomyosarcoma presenting as a gastric wall abscess. Am J Gastroenterol 1998;93:2241-2244.

14 Honda K, Mikami T, Ohkusa T, Takashimizu I, Fujiki K, Araki A, Shimoi K, Enomoto Y, Ariake K, Miyasaka N, Nihei Z, Oda K, Terada T: Gastrointestinal autonomic nerve tumor with giant abscess. A case report and literature review. J Clin Gastroenterol 1997;24:280-285.

15 Demetri GD, von Mehren M, Blanke CD, Van den Abbeele AD, Eisenberg B, Roberts PJ, Heinrich MC Tuveson DA, Singer S, Janicek M, Fletcher JA, Silverman SG, Silberman SL, Capdeville R, Kiese B, Peng B, Dimitrijevic S, Druker BJ, Corless C, Fletcher CD, Joensuu H: Efficacy and safety of imatinib mesylate in advanced gastrointestinal stromal tumors. N Engl J Med 2002;347:472-480. 


\section{Case Reports in Gastroenterology}
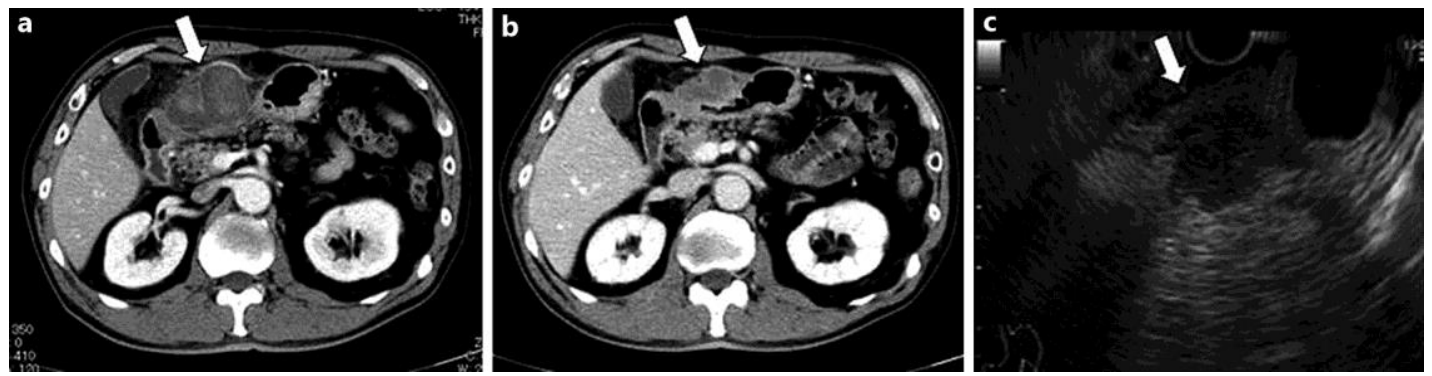

Fig. 1. a A contrast-enhanced CT scan of the abdomen on admission day revealed a mass (white arrow) of mixed solid and fluid components, measuring $5.0 \mathrm{~cm}$, adjacent to the lesser curvature of the stomach. $\mathbf{b}$ The mass (white arrow) reduced in size $(5.5-3.5 \mathrm{~cm}$ ) and became homogenous as visualized on a contrastenhanced CT scan on the 7th day. c An endoscopic ultrasound examination revealed a submucosal tumor with mixed hypoechoic changes (white arrow). A fine-needle aspiration biopsy of the tumor was performed.
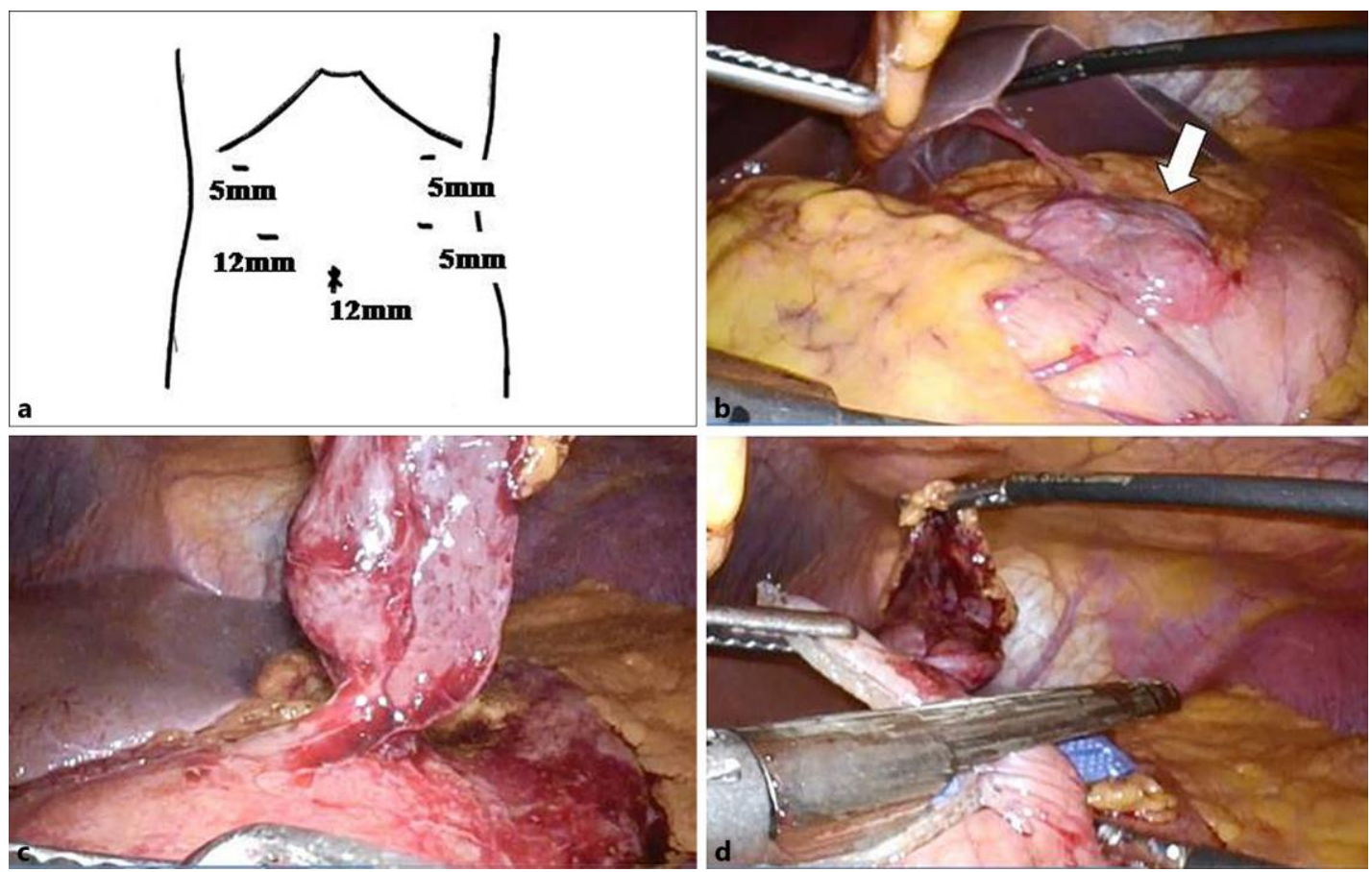

Fig. 2. a Placement of the 5 ports for laparoscopic surgery in the present case. $\mathbf{b}$ Laparoscopic findings showed that the tumor (white arrow) existed in the lesser curvature of the stomach and adhered to the omentum. c, d Wedge resection of the stomach was performed using a linear stapler, and the tumor was excised en bloc with the omentum and gastric wall. 


\section{Case Reports in Gastroenterology Case Rep Gastroenterol 2016;10:399-405 (c) 2016 The Author(s). Published by S. Karger AG, Basel www.karger.com/crg}
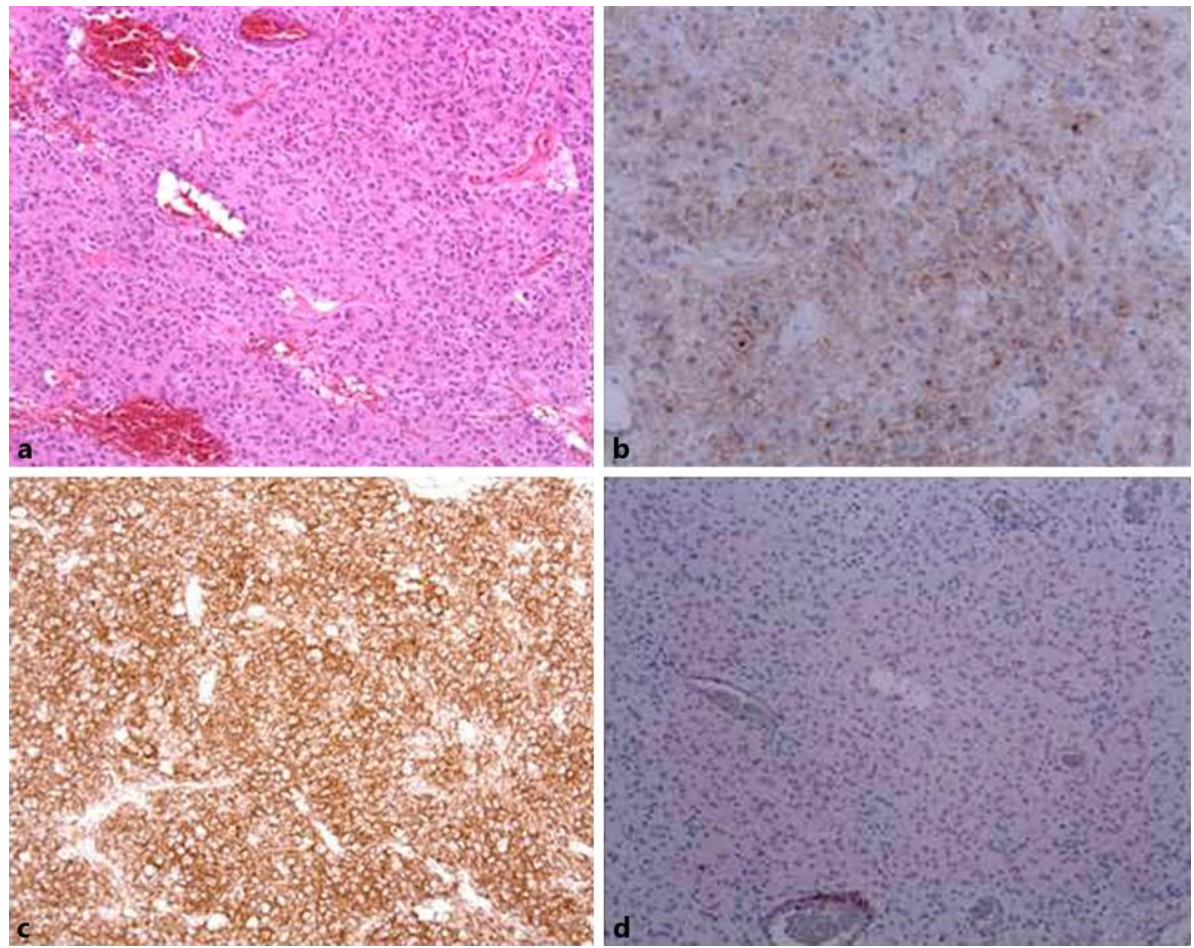

Fig. 3. a Histological findings showed spindle cells with a stromal growth pattern without necrosis. Magnification $\times 200$. $\mathbf{b}-\mathbf{d}$ Immunohistochemical staining was positive for c-kit (CD 117) and CD 34, and negative for desmin. 
Maeda et al.: Gastrointestinal Stromal Tumor of the Stomach with an Abscess Excised by Laparoscopic Surgery

Table 1. Summary of cases of GIST of the stomach with an abscess reported in the English medical literature

\begin{tabular}{|c|c|c|c|c|c|c|c|c|c|c|}
\hline \multirow{2}{*}{$\begin{array}{l}\text { Ref. } \\
8\end{array}$} & \multirow{2}{*}{$\begin{array}{l}\text { Authors } \\
\begin{array}{l}\text { Yardimci } \\
\text { et al. }\end{array}\end{array}$} & \multirow{2}{*}{$\begin{array}{l}\begin{array}{l}\text { Gen- } \\
\text { der }\end{array} \\
\text { M }\end{array}$} & \multirow{2}{*}{$\begin{array}{l}\text { Age, } \\
\text { years }\end{array}$} & \multirow{2}{*}{$\begin{array}{l}\begin{array}{l}\text { Loca- } \\
\text { tion }\end{array} \\
\text { upper }\end{array}$} & \multirow{2}{*}{$\begin{array}{l}\text { Endoscopic } \\
\text { findings } \\
\text { SMT with ulcer }\end{array}$} & \multirow{2}{*}{$\begin{array}{l}\begin{array}{l}\text { Presence } \\
\text { of fistula } \\
\text { or ulcer }\end{array} \\
\text { Ulcer }\end{array}$} & \multirow{2}{*}{$\begin{array}{l}\text { Tumor } \\
\text { necrosis }\end{array}$} & \multicolumn{2}{|c|}{ Diameter, cmAccess } & \multirow{2}{*}{$\begin{array}{l}\text { Surgical } \\
\text { procedure }\end{array}$} \\
\hline & & & & & & & & $17 \times 9$ & Open & \\
\hline 9 & $\begin{array}{l}\text { Swain } \\
\text { et al. }\end{array}$ & $\mathrm{F}$ & 38 & middle & SMT & None & None & $8 \times 6$ & Open & $\begin{array}{l}\text { PG with transvers } \\
\text { colectomy }\end{array}$ \\
\hline 10 & $\begin{array}{l}\text { Altaca } \\
\text { et al. }\end{array}$ & $\mathrm{F}$ & 74 & n.s. & n.s. & n.s. & Necrosis & $20 \times 15$ & Open & PG with SP and DP \\
\hline 11 & $\begin{array}{l}\text { Osada } \\
\text { et al. }\end{array}$ & $\mathrm{M}$ & 74 & upper & SMT with fistula & Fistula & $\begin{array}{l}\text { Central } \\
\text { necrosis }\end{array}$ & $12 \times 10$ & Open & PG \\
\hline$\overline{12}$ & $\begin{array}{l}\text { Nozawa } \\
\text { et al. }\end{array}$ & $\mathrm{M}$ & 74 & lower & Ulcer & Ulcer & n.s. & $13 \times 12$ & Open & $\mathrm{PG}$ \\
\hline$\overline{13}$ & $\begin{array}{l}\text { Seidel and } \\
\text { Burdick }\end{array}$ & $\mathrm{F}$ & 50 & middle & SMT with ulcer & Ulcer & $\begin{array}{l}\text { Central } \\
\text { necrosis }\end{array}$ & $6 \times 5$ & Open & WR \\
\hline \multirow[t]{2}{*}{14} & $\begin{array}{l}\text { Honda } \\
\text { et al. }\end{array}$ & $\mathrm{F}$ & 78 & middle & SMT with fistula & Fistula & $\begin{array}{l}\text { Central } \\
\text { necrosis }\end{array}$ & $10 \times 8$ & Open & $\mathrm{PG}$ \\
\hline & $\begin{array}{l}\text { Present } \\
\text { case }\end{array}$ & $\mathrm{M}$ & 70 & middle & SMT & None & None & $3 \times 2$ & Laparoscopic & WR \\
\hline
\end{tabular}

SMT = Submucosal tumor; $\mathrm{WR}=$ wedge resection of the stomach; $\mathrm{PG}=$ partial gastrectomy; $\mathrm{SP}=$ splenectomy; $\mathrm{DP}=$ distal pancreatectomy; n.s. = not stated. 